\title{
TEORETICKÉ MODELY PŮSOBENÍ UMĚLECKÉ INTENCE NA DIVÁKA A JEJICH EXPERIMENTÁLNÍ OVĚŘENÍ
}

\author{
PETR ADÁMEK \\ 3. lékařská fakulta Univerzity Karlovy; Národní ústav duševního zdraví; \\ kognitivní laboratoř Univerzity Palackého v Olomouci \\ E-mail: petr.adamek@nudz.cz
}

\begin{abstract}
Theoretical models of the effect of artistic intention on the viewer and their experimental verification.

The image is often discussed as a tool of the communication process across many disciplines, including the history of art and aesthetics. At present, it is also becoming of importance to cognitive sciences, which until recently have focused mainly on the basic physical properties of artefacts and how these aspects are able to influence the basic variables of our perception. However, the process of visual perception and the associated mental cognition in relation to authorial intention remained a somewhat neglected aspect. The paper presents hypotheses and theories discussing the influence of artistic intent on spectator perception and the possibilities of their application in experimental research.

Keywords: psychology of art; eye movements; photography; paintings; artist's intention
\end{abstract}

K formování významu uměleckého díla v mysli diváka dochází několika ve své podstatě odlišnými způsoby. Umělec může podávat rozhovory, psát prohlášení o svém díle a divák je může anebo nemusí číst. Taktéž se mu nabízí možnost dozvědět se o významu uměleckého artefaktu skrze texty kritiků či historiků umění snažících se o komplexní uchopení problematiky a analýzy díla v kontextu aktuální tvorby a konsensu. Skrze tyto postupy je divákům nabízena pomoc s interpretací a tím, jak dílo chápat. Všechny zmiňované postupy před diváka kladou již prefabrikovaný názor a dílo se tak postupně skrývá za řadu více či méně relevantních interpretací, které jsou jakýmsi sekundárním nástrojem výkladu: význam je totiž manifestován jakožto vnější charakteristika utvářená a do artefaktu projektovaná tím, kdo na něj nahlízíi.

V osmdesátých letech 20. století se však začalo mimo jiné o díle uvažovat jako o indexu své doby, nesoucím si ve své struktuře pozůstatky okolností svého vzniku. ${ }^{1}$ Michael Baxandall o uměleckém díle uvažuje jako o řešení určitého problému postaveného před umělce, který se poté v díle do jisté míry otiskl. Jako př́klad uvedme složitou a do značné míry unikátní kompozici Manetova obrazu Un bar aux Follies-Bergère (1882), vyžadující malírovu pečlivou př́pravu a rozvahu. Thierry de Duve doplňuje, že takováto kompozice nemohla být dílem náhody a Manetův záměr se vepsal hluboko do struktury obrazu

1 David Summers, Form. Nineteenth-Century Metaphysics, and the Problem of Art Historical Description, Critical Inquiry XV, 1989, č. 2, s. 372-406. Dostupné online na www.jstor.org/stable/1343590, vyhledáno 20. 10. 2016. 
samotného a pro oko pozorného diváka by tudíž neměl zůstat skryt. ${ }^{2}$ Důležitou charakteristikou podílející se na interpretaci se tak dle zmiňovaných teorií stává vnější tvar objektu a vnitřní (kompozice) fyzická struktura díla. Porozumění výtvarnému dílu by se tím pádem dalo v extrémním případě redukovat pouze na snahu popsat tyto dva základní aspekty, tedy tvar a kompozici, a následně z nich odvozovat význam a funkci artefaktu. Z interpretačního procesu by proto viděno tímto prismatem vypadla snaha autora zařadit umělecký objekt do určité kategorie, tedy tzv. kategorická intence autora, kterou Jarrold Levinson spojuje s kulturní identitou ${ }^{3}$ a označuje ji za zásadní významotvorný činitel. $\mathrm{V}$ našem světě existuje celá řada objektů, u nichž bychom bez znalosti autorské intence nebyli schopni objekt správně pojmenovat/zařadit ${ }^{4}$ a dopouštěli bychom se dezinterpretace. Vezměme si např́klad středověká ciboria, která mohou mít mimo jiné tvar kalichu, za nějž může laik ciborium zaměnit. Ovšem kalich není ciborium. Problematika tvaru je silně artikulována i v eseji Michela Foucaulta „Ceci n’est pas une pipe ${ }^{\text {“5 }}$ na př́kladu stejnojmenného Magrittova obrazu: „bez nejasností a zaváhání nechá vyjevit to, co reprezentuje (vyobrazení dýmky - pozn. autora). Je jakoukoli stopou, která na papíre nebo na tabuli uchovává trochu tuhy nebo kř́dového prachu <neodkazuje> jako šipka nebo ukazatel na vzdálenou či neprrítomnou dýmku; je sama dýmkou." 6

Vyobrazení se stává dýmkou, poněvadž divák je př́liš zaujatý formou a je dle Foucaulta vězněm reprezentace tvaru. Magritte se však svou slovní hříčku „Ceci n'est pas une pipe " snaží diváka z tohoto vězení vysvobodit a do obrazu dokonce vkládá samu instrukci, čímž nepřímo podporuje tvrzení o důležitosti intence v interpretačním procesu. ${ }^{7}$ Magritte i Foucault poukazovali na fakt, že slovní označení objektu X může být použito i při pojmenovávání vizuální reprezentace $\mathrm{X},{ }^{8}$ ale nemělo by s ní být zaměňováno. Vyobrazení dýmky a její následné „popření však vzniklo na základě vědomého intencionálního rozhodnutí autora nakreslit dýmku. V tuto chvíli samozřejmě do hry vstupuje velké množství aspektů formujících schopnosti autora vytvořit vyobrazení. Jsou jimi například zkušenost a médium, ${ }^{9}$ ale také historický a kulturní kontext, v nichž vyobrazení vzniká, a které kladou autorovi také jisté limity. ${ }^{10}$ Vyobrazení vikingského drakaru bude mít jen málo společných rysů s futuristickým konceptem lodí třídy Littoral amerického námořnictva, avšak v očích dnešního diváka budou obě vyobrazení označena za lod'. Jedná se totiž o intersubjektivní interpretaci, jež je sice formována skrze kulturní encyklopedii ${ }^{11}$ a topoi, v níž se vyskytujeme. Nicméně je možné prohlásit, že jsme schopni z uskupení

2 Thiery de Duve, Intentionality and Art Historical Methodology. A Case Study, Nonsite.org, č. 6 (Intention and Interpretation) [online], http://nonsite.org/article/intentionality-and-art-historical-methodology-a-case-study, vyhledáno 20. 12. 2017.

3 Viz Jerrold Levinson svou koncepci intencionální/historické teorie poprvé představil v eseji Extending Art Historicaly. (Jerrold Levinson, Extending art historically, Journal of Aesthetics and Art Criticism LI, 1993, č. 3, s. 411-423.)

4 Paul Bloom, Intention, History, and Artifact Concepts, Cognition LX, 1996, č. 1, s. 1-29.

5 Michel Foucault, This Is Not a Pipe, London 1983.

Ibidem, cit s. 20.

7 Viz Bloom (pozn. 4).

8 Ibidem.

9 David Summers, Intentions in the History of Art, New literary history XVII, 1986, č. 2, s. 305-321.

10 Arthur C. Danto, The Philosophical Disenfranchisement of Art, Grand Street IV, 1985, č. 3, s. 171-189.

11 Viz Petr Bílek, Reprezentace: Metafora, pojem či koncept?, in: Veronika Vebrová - Petr Bílek - Vladimír Papoušek et al. (edd.), Jazyk reprezentace, Praha 2012. 
barevných skvrn či linií rozpoznat určitý tvar a následně mu přiřadit některou „obecnou“ kategorii nebo př́slušnost k určitému hmotnému projevu reality. ${ }^{12}$

Linie artefaktu, respektive jeho fyzická struktura zahrnující autorskou intenci, tedy hrají důležitou roli v naší schopnosti kategorizovat a dekódovat významy objektů. Často se tak mluví o afordanci ${ }^{13}$ objektu (uměleckého díla), přesněji o jeho sociokulturní stránce závislé na primárním účelu jeho existence, a to jak je divák schopen s daným objektem interagovat, potažmo jej interpretovat na základě jeho pouhého vzhledu. Artefakt tedy $\mathrm{s}$ určitostí spadá do kategorie $\mathrm{X}$ pouze $\mathrm{v}$ případě, pokud víme, že intencí autora bylo objekt do této kategorie zařadit.

V předcházejících odstavcích jsme nastínili několik př́ípadů, které by se daly označit obecným pojmem sémantické intence, ${ }^{14}$ tedy intence skládající se z podnětů poukazujících na význam díla, nikoli však z intence podílející se na jeho vnitřní konstituci. ${ }^{15} \mathrm{Za}$ tu bývá běžně označována intence kategorická. ${ }^{16}$ Ta na rozdíl od svého protějšku není vnější charakteristikou vyplývající z „viditelných“ vlastností uměleckého díla, ale je jeho vnitřní formou, kterou není možné abstrahovat, a tudíž by ji nemělo být možné „volněc číst. Jedná se o vnitřní status díla - objektu interpretace. ${ }^{17}$ Pokud ale opravdu přistoupíme na toto tvrzení, není jakákoli snaha o zevrubnější interpretaci uměleckého artefaktu naprosto znemožněna? Je kategorická intence skrze dílo opravdu nepřenositelná na diváka, a k její př́padné rekonstrukci je potřeba sekundárních pramenů? Domnívám se, že nikoli!

Levinson předpokládá, že bez kategorické intence by interpretaci chyběl jakýkoli rámec, a ta by z tohoto důvodu neměla jasný začátek ani konec, a tudíž by se „možnosti výkladu etiologií staly ve své podstatě prakticky bezbřehé “ 18 V roce 1986 Flint Schier ve své knize Deeper into Picture prezentuje teorii, podle níž je interpretace díla závislá na intenci umělce, která ovlivňuje percepci díla. Uvádí, že kategorická intence musí být pro diváka v jistém smyslu viditelná, čímž mu umožní připsat konkrétní intence autorovi, a to na základě jeho setkání s uměleckým dílem. Podrobněji byl tento přístup rozpracován v sérii článků Allesandra Pignocchiho (2010, 2012). Pignocchi se táže: „Jaký je psychologický mechanismus, který dovoluje divákovi čist autorskou intenci a jak toto čtení souvisí se samotnou percepcí obrazu?" V jeho intencionálním modelu nemusí být čtení autorské intence na vědomé úrovni, jedná se o „implicitní i explicitní, vědomé i nevědomé úmysly a duševní stavy, které stály za vznikem uměleckého artefaktu“. ${ }^{19}$ Současné výzku-

12 Hans Gombrich ve svém popisu zlaté plakety umístěné na palubě Voyageru 1 upozorňuje na stejnou problematiku, tedy na schopnost naší interpretace až na základě zkušenosti a kulturního kontextu. (Viz František Mikš, Gombrich - Tajemství obrazu a jazyk umění, Brno 2008, s. 48-49.)

13 James J. Gibson, The Theory of Affordances, in: Robert Shaw - John Bransford (edd.), Perceiving, Acting, and Knowing, Mahwah 1977. - James J. Gibson, The Ecological Approach to Visual Perception, Oxford 2014. - Ladislav Kesner, Intence, affordance a význam kulturních objektů, in: Jiří Kroupa Michaela Šeferisová-Laudová - Lubomír Konečný (edd.), Orbis Artium, Brno 2009, s. 59-73.

14 O problematice sémantické intence viz Paisley Livingston, Intentionalism in Aesthetics, New Literary History XXVIII, 1998, č. 4, s. 831-846. - Jerrold Levinson, Intention and Interpretation in Literature, in: idem, The Pleasure of Aesthetics. Philosophical Essays, Ithaca 1996, s. 175-213.

15 Ibidem, s. 183.

16 Ibidem, s. 188.

17 Mark Rollins, What Monet Meant. Intention and Attention in Understanding Art, The Journal of Aesthetics and Art Criticism LXII, 2004, s. 175-188.

18 Jerry A. Fodor, Déjà vu all Over Again: How Danto’s Aesthetics Recapitulates the Philosophy of Mind, in: Mark Rollins (ed.), Danto and his Critics. Second Edition, Chichester 2012, s. 55-68.

19 Allesandro Pignocchi, L'euvre d'art et ses intentions, Paris 2012, cit. s. 115. 
my na poli kognitivních věd, které se zabývají intencionálními postoji člověka, dávají tomuto modelu za pravdu. ${ }^{20}$ Výzkum malírské intence se však díky specifickému médiu v podobě uměleckého díla částečně liší. Pignocchi mluví o takzvaných intencionálních akcích umělce, k jejichž odkrývání dochází skrze motorický systém v divákově mozku a ten je schopen reprodukovat a zrcadlit motorické aspekty vzniku díla. Pignocchiho teorie však popisuje pouze jednu vrstvu autorské intence, a sice tu zodpovědnou za strukturální aspekty malby, jakým jsou tahy štětce a plasticita barvy, tedy kategorickou intenci.

Současná kognitivní věda nabízí obecnou teorii zastřešující jak sémantickou, tak i kategorickou/motorickou složku intence a jejich vzájemnou interakci ve společném kaskádovém modelu. Elisabeth Pacherie pojmenovává tř̌i základní složky intence, které jsou zároveň v hierarchizovaném pořadí. Takzvané distální intence (potencionální, možné, nebo také do budoucna směřované - za její analogii můžeme považovat koncept zmiňované sémantické intence) jsou v kontextu malířské tvorby zodpovědné za koncepce a nápady vedoucí $\mathrm{k}$ tvorbě díla. Dále je to proximální intence (aktuální, směřované do současnosti - za její analogii můžeme považovat kategorickou intenci). Zde se již bavíme o převedení myšlenek do samotného média malby, tedy o akci, při níž dostávají prvotní myšlenky fyzickou formu. Poslední rovinou jsou motorické intence, v nichž můžeme spatřit schopnosti umělce, jako je zručnost či talent, ale např́iklad i aktuální psychické rozpoložení. Mezi jednotlivými složkami je možné vysledovat kauzální vztah, a tedy lze hovořit o tzv. intencionální kaskádě. [Obr. 1] Přechod od distálních k proximálním intencím zahrnuje také transformaci deskriptivního a konceptuálního obsahu do vizuálně vnímatelného spektra a ten se tak stává indexem původní ideje. Tato koncepce tak otevírá možnosti, jak pomocí experimentálních postupů částečně rekonstruovat distální, proximální a motorické intence, přesněji řečeno jejich index. Divákův zkoumající pohled na obraz je totiž v prvních okamžicích ovlivněn jeho vizuálními kvalitami, jež jsou souhrnem konkrétních formálních vlastností díla ${ }^{21}$ a podílejí se na jeho celkové vizuální a následné sémantické a afektivní salienci. ${ }^{22}$ Tímto zpo̊sobem jsme v díle schopni nalézt konkrétní prvky, jež konstituují jeho vnímání. Záznam okulomotorického chování oka je tedy ovlivněn proximálními a zejména motorickými intencemi. Tato skutečnost

20 Angela Ciaramidaro et al., Do you mean me? Communicative intentions recruit the mirror and the mentalizing system, Social cognitive and affective neuroscience IX, 2013, č. 7, s. 909-916. - Caroline Catmur, Understanding intentions from actions: Direct perception, inference, and the roles of mirror and mentalizing systems, Consciousness and cognition XXXVI, 2015, s. 426-433.

21 Barevnost, komplexnost (Davide Massaro et al., When Art Moves the Eyes. A Behavioral and Eye-tracking Study, PloS one VII, 2012, č. 5, dostupné online na http://journals.plos.org/plosone /article?id=10.1371/journal.pone.0037285, vyhledáno 10. 8. 2015.), dynamismus (ibidem), prostorovou frekvenci (Sabira K. Mannan - Keith H. Ruddock - David S. Wooding, Automatic Control of Saccadic Eye Movements Made in Visual Inspection of Briefly Presented 2-D Images, Spatial vision IX, 1995, č. 3, s. 363-386.), kontrast, luminositu (Tien Ho-Phuoc et al., When Viewing Natural Scenes Do Abnormal Colors Impact on Spatial or Temporal Parameters of Eye Movements?, Journal of Vision XII, 2012, č. 2. - Antje Nuthmann - George L. Malcolm, Eye Guidance during Real-world Scene Search. The Role Color Plays in Central and Peripheral Vision, Journal of Vision XVI, 2016, č. 2.), kompozici, hloubku ostrosti u fotografie, perspektivu, počet objektů ve scéně (Kai Kaspar - Peter Koenig, Viewing Behavior and the Impact of Low-level Image Properties across Repeated Presentations of Complex Scenes, Journal of Vision XI, 2011, č. 13. - Calen R. Walshe - Antje Nuthmann, Mechanisms of Saccadic Decision Making while Encoding Naturalistic Scenes, Journal of Vision XV, 2015, č. 5.).

22 Tedy tomu jak a které části vnímaného vizuálního pole přitahují naši pozornost; viz Adámek (pozn. 13). 
nám však prozatím nedovoluje říci nic o autorském záměru. Ten by bylo možné z média malby abstrahovat až na základě určitého kontrastu odkazujícího na tvůrčí proces. Tímto kontrastem se poté v určitých př́padech může stát fotografie, a to tehdy, pokud umělci sloužila jako referenční médium pro jeho tvorbu. Porovnáním záznamu optomotorických drah divákova zkoumajícího pohledu mezi referenční fotografií a malbou tak dostaneme kontrast, $v$ němž vidíme místa odkazující k motorickým a distálním intencím autora. Problematickým aspektem je poté samotná struktura kaskádovitého modelu, jež nedovoluje rekonstruovat otisky autorské intence rovnoměrně. [Obr. 1] Čím blíže se nacházíme centru pyramidy, tím více jsou distální intence autora zastřeny nánosy proximálních a motorických intencí, a v neposlední řadě i možných náhod. Jak vidíme na pyramidálním schématu, motorické intence je možné rekonstruovat nejpřesněji.

K verifikaci výše představeného teoretického modelu byl vytvořen eyetrackingový experiment. ${ }^{23} \mathrm{Na}$ základě statisticko-analytických metod aplikovaných na záznam okulomotorických pohybů divákova oka byla nalezena místa, která autor v procesu tvorby moduloval a také to, jak tyto změny ovlivňovaly divákův pohled. Experiment potvrdil i hierarchické uspořádání intencionální kaskády. Záznam proximálních a motorických intencí bylo možné na základě statistické analýzy popsat a do jisté míry i abstrahovat z uměleckého díla. U distálních intencí je situace značně složitější, jejich podoba byla popsána pouze na základě statistického výpočtu vztahujícího se k intencím motorickým a proximálním, díky čemuž není možné stoprocentně říci, jak a zda vůbec se distální intence podílejí na divákově percepci. I přes tuto skutečnost jsme se pokusili o potvrzení účinku distálních intencí na recipienta pomocí šesti př́ípadových studií. Zde autoři maleb popisují, jak chtěli, aby dílo působilo na diváka a jakými konkrétními prvky toho mělo být dosaženo. Autoři popsali stejné prvky, jaké vyplynuly ze statistické analýzy, avšak vzhledem k malému počtu př́ípadových studií není možné stoprocentně prohlásit, že distální intence mohou být odvozeny ze statistického záznamu intencí motorických a proximálních: tento závěr bude nutné potvrdit v některé z následujících studií.

K odkrývání intencionálního záměru tak docházelo vždy a v plné míře a naše čtení odhaluje pouze některé jeho vrstvy. Distální intence stojící za samotným vznikem díla, ale zároveň nejdále od diváka, jsou nejhưře čitelné a pravděpodobně často nejsou popsatelné ani samotným umělcem, jenž může koncepci díla vytvářet i na zcela intuitivní, částečně vědomé či nevědomé úrovni. Nižší vrstvy kaskády, především motorické intence, jsou divákovi o něco dostupnější. Jelikož je v řetězci obsaženo méně ostatních, na autorově intenci nezávislých, proměnných, viz obr. 1 - boční části pyramidy), je pravděpodobnější, že ovlivní divákovu percepci a tím i celkové chápání uměleckého díla ve směru, jaký autor při jeho tvorbě na rovině motorických intencí do díla zasadil.

\section{Poděkování}

Tento článek je výsledkem badatelské činnosti podporované projektem číslo LO1611 za finanční podpory MŠMT v rámci programu NPU I.

23 Petr Adámek - Dominika Grygarová - Jiř́i Lukavský et al., Tracking artistic transformations: Comparing paintings and their source photographs, I-Perception 2018 (v recenzním řízení; ID: IPE-17-0156). 


\section{LITERATURA A PRAMENY}

Petr Adámek - Dominika Grygarová - Jiří Lukavský et al., Tracking artistic transformations: Comparing paintings and their source photographs, I-Perception 2018 (v recenzním řízení; ID: IPE-17-0156).

Petr Adámek, Akční skript a jeho kulturněhistorická poloha (seminární práce), Seminář dějin umění FF MU, Brno, 2014.

Petr Bílek, Reprezentace: Metafora, pojem či koncept?, in: Veronika Vebrová - Petr Bílek - Vladimír Papoušek et al., (edd.), Jazyk reprezentace, Praha 2012.

Paul Bloom, Intention, History, and Artifact Concepts, Cognition LX, 1996, č. 1, s. 1-29.

Caroline Catmur, Understanding intentions from actions: Direct perception, inference, and the roles of mirror and mentalizing systems, Consciousness and cognition XXXVI, 2015, s. 426-433.

Angela Ciaramidaro et al., Do you mean me? Communicative intentions recruit the mirror and the mentalizing system, Social cognitive and affective neuroscience IX, 2013, č. 7, s. 909-916.

Arthur C. Danto, The Philosophical Disenfranchisement of Art, Grand Street IV, 1985, č. 3, s. 171-189.

Thiery De Duve, Intentionality and Art Historical Methodology. A Case Study, Nonsite.org, č. 6 (Intention and Interpretation), http://nonsite.org/article/intentionality-and-art-historical-methodology-a-case -study, vyhledáno 20. 12. 2017.

Jerry A. Fodor, Déja vu All Over Again, Danto and his Critics. Second Edition, 1993, s. 55-68.

Michel Foucault, This Is Not a Pipe, London 1983.

James J. Gibson, The Ecological Approach to Visual Perception, Oxford 2014.

James J. Gibson, The Theory of Affordances, in: Robert Shaw - John Bransford (edd.), Perceiving, Acting, and Knowing, Mahwah 1977.

Tien Ho-Phuoc, et al., When Viewing Natural Scenes Do Abnormal Colors Impact on Spatial or Temporal Parameters of Eye Movements?, Journal of Vision XII, 2012, č. 2.

Peter Koenig - Kai Kaspar, Viewing Behavior and the Impact of Low-level Image Properties across Repeated Presentations of Complex Scenes, Journal of Vision XI, 2011, č. 13.

Ladislav Kesner, Intence, affordance a význam kulturních objektů, in: Jiří Kroupa - Michaela ŠeferisováLaudová et al., Orbis Artium, Brno 2009, s. 59-73.

Jerrold Levinson, Extending art historically, Journal of Aesthetics and Art Criticism LI, 1993, č. 3, s. 411-423.

LJerrold Levinson, Intention and Interpretation in Literature, in: idem, The Pleasure of Aesthetics. Philosophical Essays, Ithaca 1996, s. 175-213.

Paisley Livingston, Intentionalism in Aesthetics, New Literary History XXVIII, 1998, č. 4, s. 831-846.

Sabira K. Mannan - Keith H. Ruddock - David S. Wooding, Automatic Control of Saccadic Eye Movements Made in Visual Inspection of Briefly Presented 2-D Images, Spatial vision IX, 1995, č. 3, s. 363-386.

Davide Massaroet al., When Art Moves the Eyes. A Behavioral and Eye-tracking Study, PloS one VII, 2012, č. 5., http://journals.plos.org/plosone/article?id=10.1371/journal.pone.0037285, vyhledáno 10. 8. 2015.

František Mikš, Gombrich - Tajemství obrazu a jazyk umění, Brno 2008, s. 48-49.

Antje Nuthmann - George L. Malcolm, Eye Guidance during Real-world Scene Search. The Role Color Plays in Central and Peripheral Vision, Journal of Vision XVI, 2016, č. 2.

Allesandro Pignocchi, L'ouvre d'art et ses intentions, Paris 2012, cit. s. 115.

Mark Rollins, What Monet Meant. Intention and Attention in Understanding Art, The Journal of Aesthetics and Art Criticism LXII, 2004, s. 175-188.

David Summers, Form. Nineteenth-Century Metaphysics, and the Problem of Art Historical Description, Critical Inquiry XV, 1989, č. 2, s. 372-406.

David Summers, Intentions in the History of Art, New literary history XVII, 1986, č. 2, s. 305-321.

Calen R. Walshe - Antje Nuthmann, Mechanisms of Saccadic Decision Making while Encoding Naturalistic Scenes, Journal of Vision XV, 2015, č. 5. 


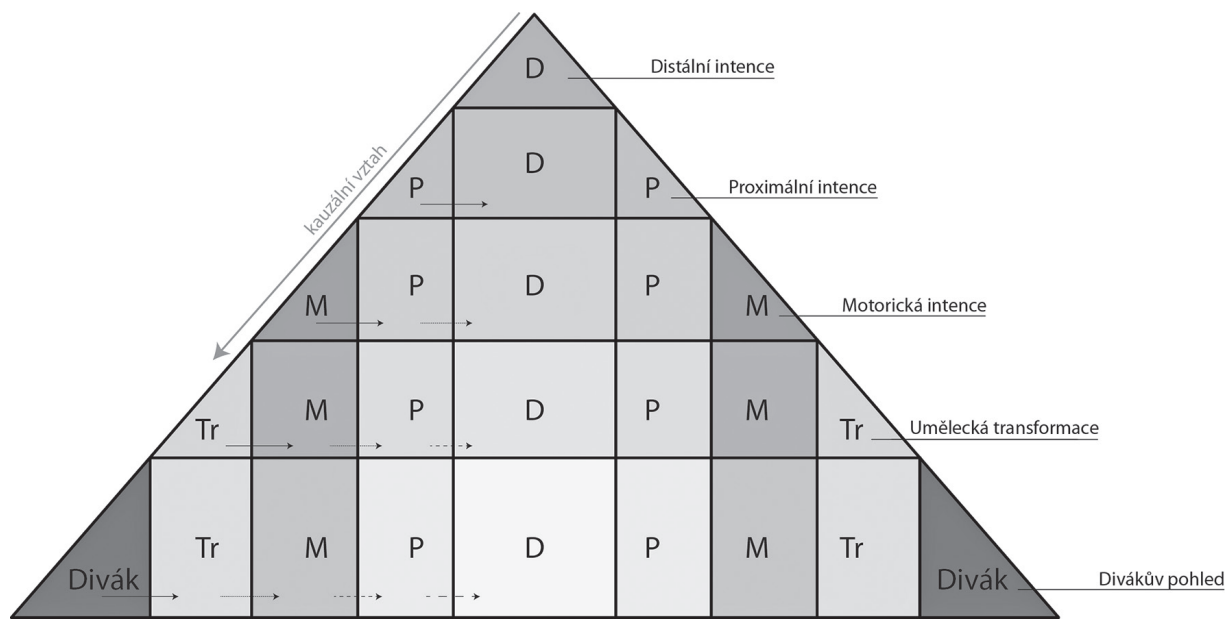

Obrázek 1: Intencionální kaskáda 